\title{
A Short account of the historical geography of Early Assam
}

\author{
Rabindra Das M.A.LL.B. \\ Asstt. Prof. Dept. of HistoryB.N.College. Dhubri,Assam
}

\begin{abstract}
The study of historical geography now becomes one of the important components for discovery of early history in accurate form. From ancient time Indian philosophers and writers of Dharmasastra paid more attention on man's respect for and concern to his environment -hills, rivers, trees, stones, birds, animals and so forth. In Assam also people had faith on natures as in mentioned in the 'Kalikapurana' Epigraphic records of early Assam focused many important facts as related to society. Assam or North-east India had little written records for which authors have to rely on or inclined to geographical factors for formation of history in early society. The basic objective of the study of historical geography is to mark out the history of geographical changes of a particular time and space thereby to find out the trend of socio-politio-economic changes for reconstruction of history. The inscriptions of early Assam made tremendous contribution in the reconstruction of the socio-politio-economic history of the region. B.K.Barua, M.M.Sarma, Nirad Barua, I. Sarkar etc. made valuable contribution for the study of historical geography in right perspective and they also introduced geographical factors elaborately as a right component for reconstruction of early Assam history.

Keywords: Assam, Copper plate, Historical geography, Inscriptions, North-East India, Study
\end{abstract}

\section{Introduction}

Historical geography covers the domain of geography as part of social-historical formation as both history and geography are very closely related in the process of formation and development of society, polity and economy. The basic objective of the study of historical geography is to mark out the history of geographical changes of a particular time and space and thereby to find out the trend of polico-socio-economic changes for reconstruction of history. Assam or the north-east India is a place where most societies in ancient past had but little written records, habitat of a multiples of ethnic and tribal communities having multifarious speech forms vastly differing from one another leading to form a complex situation in identification of many ancient site and situations, Therefore attempts have made to trace out the geographical history of early Assam to focus on the formation of the history of the place names on the basis of linguistic and onomastic understanding. It is also an attempt to study the historical geography of early Assam by analyzing data from the inscription of Assam belonging to the period from $5^{\text {th }}$ to $13^{\text {th }}$ century A.D.

Geography is the science of the surface of the Earth and it's in habitats. It is description of man's relationship over the surface of the Earth. Generally geography is divided into two broad categories. The first, physical geography which deals with the studies the configuration of the Earth surface, its water, vegetations, animal life, climate etc. While the second, Human or cultural geography related with the demographic (distribution of population over territory), political (distribution of territory among states) and economic geography (distribution of natural resources, production centers, land utilization, trade, transport etc.). Thus, geography as an indispensable component forms the basis of historical geography. Hartshorhe defines historical geography as "an attempt to reconstruct the geography of a period of historical past." Thus, physical and human changed were took place in aparticular region in the past by the factor of historical geography. Again, the population structure and demographic history of a region can be estimated from the extent of forests, deserts and cultivated zones, and such type of study also important for the formation of the socio-economic history in general. In this regard V.S. Agarwala remarks that geography and chronology are said to be the two eyes of the history.

\section{Historical geography of Early Assam}

Most of thegeographical names found in the inscriptions and literary sources belonging to the period from the $5^{\text {th }}$ to the $13^{\text {th }}$ century A.D.of Assam only with applying the conventional methodology. The inscriptions of early Assam provide distinct and recognizable contribution in the formation of the socio-politicoeconomic history of the region. There have been thirty-eight inscriptions (38) belonging to the period of $5^{\text {th }}$ to $13^{\text {th }}$ century A.D. discovered, out of these twenty-three are records of lands granted to the Brahmans and others are short stone image inscription; inscribed clay seals, royal notices in the form of stone inscription and stone pillar inscription, which provides 13 sacred geographical names, 20 names of rivers and streams, 100 names of administrative divisions and plots of lands and 16 place-names of outside early Assam. The identification of 
these geographical names is very much essential in the study of the social and polity formation, processes of sanskritisation etc. But unfortunately, except few these names are still not properly identified and located. The biggest hurdle in this respect as mentioned earlier is the lack of corroborative evidence. Therefore, we put forword some methods, which can be applied exclusively for the study of geographic provenance of the inscription of early Assam. These methods are basically simple with distinct objectives and drawn from the broad area of the conventional methodology.

Lack of supporting documents in determination of geographic provenance of an inscription, it may be taken into consideration the place of discovery of the inscription. Because it may indicate a right direction to trace out a geographical provenance of an area that mentioned in the inscriptions. Generally in case of the stone inscription, those were inscribed on natural boulders or bigger walls, for which the reported find-spot can easily be determined as its original place. The Nidhanpur Copper Plate Inscription of Bhaskaravarman may be taken as one of the best examples where the places of discovery indicated a right direction in the determination of its geographic provenance. Of course this method cannot always be effective in regard to provide us with necessary geographic information of the places mentioned in the inscription.

Another method for further enquries of the geographic provenance, i.e. by searching the names of administrative units such as districts, villages etc. find mention in the inscription within which the donated land lay. The knowledge of the approximate area of the administrative divisions helps us to determine the tentative area of the donated land. By applying this method in the Caratbari Copper Plate Inscription and the Suwalkuchi Copper Plate Inscription of Ratnapala of Pala dynasty we may identify the location of the donated land with the region of the present Habung (an area of present Dhakuakhana in the North Lakhimpur )

The proximity to one or more rivers or rivulets, hills, villages etc. found in the grants helps us to locate donated lands, though it is almost impossible to trace out the locations of all the rivers and rivulets due to changes in their courses in different points of time, even some of them already died or dried up, yet some of the names of the rivers and rivulets found in the inscriptions may help us to provide useful information as a careful study of the pattern of nomenclature and the names of the rivers of present east and north east India may show the link with the older one found in the early inscriptions. As for example we can say that with the help of a name of one Bekkasuska (a dried up river called Bekka) found in the Pushpabhadra Copper Plate Inscription as the southern boundary of the donated land which is compared with the river Beki and we may identify the location of Puraji visaya of the charter.

Finally onomastics may provide us with ample scope to study the origin and the method of transformation of the names from one form to another and thereby, we may link them with the present geographical names. This method is generally applied when other geographic information is not cleared. Today, onomastics is a full blown branch of socio-linguistic study of proper names with the help of same scientific method. In Assam Satendra Nath Goswami, Promad Bhattacharya, Hem Burhagohain etc. made valuable contributions towards the onomastic study in Assam. Sarat Kumar Phukan composed (wrote ) series of books like ' Toponymy of Assam', 'A study of Hodonymy', 'A few aspects of place name study with special reference to Assam' etc. with the help of onomastics.

In regard to the study of the historical geography of early Assam no specific attempt has been made after the work of B.K.Baruah by the use of new sources (inscription). M.M.Sarma, a Sanskrit scholar of Assam has published the inscriptions of Ancient Assam in 1978 which provided us a lot of geographical names found in the inscriptions and anthology of the inscriptions of early Assam. This work was able to fulfill to some extent the gap of the forty years between B.K.Baruah (early geography of Assam, 1952) and Ichchimuddin Sarkar, a scholar from North Bengal by publishing 'Aspects of historical geography of Pragjyotisha Kamrup (ancient Assam) in 1992 where geographical names found in the early inscriptions and literary sources like kalika puranas and yogini Tantra are included. This work was more systematic and based on the traditional methodology like contemporary scholars in other parts of India. One of the important contributions of his work is that some geographical names found in the medieval sources are incorporated and identified. But it fails to reflect some of the important aspects of historical geography of early Assam and also fails to careful about the actual boundary of the state of Pragjyotisha Kamrupa.

\section{Material and size of the inscriptions}

Generally four types of materials, namely copper plates, stone, "burnt clay, bronze were used for engraving the inscriptions. THE copper plates were usually bundled with a copper ring and the two ends of which were secured in a heart-shaped made of bronze or sometimes alloy of copper and bell metal. It was mainly inscribed and issued for donation purpose. Generally three plates were used in all cases except the Nidhanpur Copper Plate Inscription (seven plates), the Dubi Copper Plate Inscription (six), and the Assam .Plate. (Five) The names of the ancestors with their eulogistic virtues, an exhaustive list of the names and the gotras of the donees and the purpose of the grant etc. were inscribed thoroughly in the three copper plates for which more than three plates were used. 
The rock inscription like Umachal Rock Inscription, Tezpur Rock Inscription, Barganga Rock Inscription and the Kanaibarashi Rock Inscription were engraved on bigger and the Nagajari Khanikar Gaon Stone Inscriptio ,Deopani Vishnu Image Inscription, Hari-Hara Stone Image Inscription, Krisna Durga Stone Image Inscription and Sankar Narayan Stone Image Inscription and the silimpur stone inscription were engraved on smaller stones. The size of the copper plates vary from one another, the biggest one is the Kaliabor Copper Plate Inscription of Vanamalavarmandeva (12.8'×5)

The language of the inscriptions is Sanskrit and most of the texts of the epigraphs were composed by certain learned Sanskrit scholars. However, it cannot be denied that certain local forms were incorporated at different places of these writings, and the entry of such word forms may be due to the influence of the local dialects. Padmanath Bhattacharya in his 'kamrupa sasanavali' remarks that 'some words of the inscriptions as orthographical irregular and inaccurate'. But B.M.Barua and D.Neog showed that the said irregularities or inaccuracies had a method in them and tried to establish the existence of a local prakrit language. Again the language of the inscription is a peculiar blending of kamrupi prakrita with Sanskrit; indicate the interim stage in the development of the Assamese language. As for example all the names given in TRI of Harjaravarmana are prakritised forms and these were easily understood as these languages are related with spoken language. Another this type of inscription is the Ambari Stone Inscription of Samudrapala of the pre-Ahom period.

The development of modern Assamese language with chronological order was the result of the discovery of the Gachtal Stone Pillar Inscription of saka era 1284 (1362 A.D.) and its decipherment. P.C.Choudhury remarked that this inscription is not written in Sanskrit but in old Assamese language wherein words of Maithali and Varjabuli language of the inscriptions of ancient Assam is not a chaste-sanskrit but the Sanskrit influence by the local language or dialects which given birth to a way to the development of modern Assamese language.

Siddhamatrika or Kutila script also known as Nagri script was used in all the inscriptions of early Assam. In course of time the Brahmi script had lost its classical form and adapted to local influence and local influence does not mean the Assamese influence alone. Local cultural influence and east India regional influence are the two factors, which are being related to this transformation. As for example it may be pointed out that the dissimilarities from epigraphs, The Dubi Copper Plate Inscription and Nidhanpur Copper Plate Inscription both were issued by Bhaskarvarman from the Pragjyotishpur and the Karnasuvarna (Murshidabad, district of West Bengal) respectively. Though the inscriptions were issued by the same king, there were some differences in the shape of its letters. The East-India influence on the transformation of Brahmi script may be observed in the epigraphs of Vallbhadeva (Assam Plat.) and the Kanaibarashi Rock Inscription (12 $2^{\text {th }}$ century).

\section{Style of the writing of the inscriptions}

The style of the writing of the inscriptions was both the prose and the verse and majority of them were in mixed prose and verse, some others were written only in sanskrit prose. The copper plate inscriptions followed the nature and characteristic features of typical North Indian Copper Plate institutions. The copper plate inscriptions of early Assam may be classified as eulogistic cum donative and eulogistic cum commemorative cum donative, with the writing style of Sanskrit verse and prose, bear the typical North Indian features in their formats. In regard to the metre of the poetic portions of the inscriptions, it is found that a beautiful and high standard poetic sense of the composers in comparison to some of the other contemporary composers of the Northern India.

The inscriptions may be broadly be classified into two categories- religious and secular. The eulogistic and donatives inscriptions may be considered as religious as donations were made to the Brahmans to earn religious merits. The Secular epigraphs were mainly those, which were issued as royal notices or directives given by the kings or the local authorities or as a record of battle.

The inscriptions of the early period can be classified into the following groups:-

(a) Commemorative

(b) Royal decree

(c) Commemorative cum Donative

(d) Eulogistic cum Donative

(e) Commemorative cum Eulogistic cum Donative

Umachal Rock Inscription of Surendravarman, Barganga Rock Inscription of Bhutivarman, clay seal of Bhaskarvarman are the examples of commemorative type of inscriptions. The Tezpur Rock Inscription, HariHara Stone Image Inscription are the examples of a royal decree. The Assam Plate of Vallabhadeva, Surya Image Inscription are the commemorative cum Donative type of inscriptions. The other inscriptions so far discovered may be categorized as Eulogistic cum Donative and Eulogistic cum Commemorative cum Donative. 


\section{Contents of the inscriptions}

Generally the contents of the inscriptions may be divided into two groups- short and long. The URI, NCS, ATCS, CBI, TRI, SII, etc. are the examples of short inscriptions. There are mainly commemorative cum donative and royal decree type bear the name of the donar, done, articles, occasions or purpose of the donations. In regard to long type inscription there is no hard and fast rule. However, most of the inscriptions used the sign " $\zeta$ " as opening formula and the NCPI of Balavarman, GCPI of Indrapala, SCPI of Ratnapala etc. bear this sign as opening formula. Most of the inscriptions began with the main theme after paying tribute to Lord Shiva. Again the inscriptions carry a genealogical list of kings, mythological allusion of their ancestors. This type of comparisons and allusions, with short and long description were used in almost all the CP inscriptions of early Assam. In some inscriptions, we find mention about the battle fought by the kings and depiction of capital cities. As for example we can cite the BCPI of Ratnapala describe the capital city Durjjaya with some allusive verses as follows -

" The heart of the city Durjjaya was allayed by the shower of the drops of ichors flowing from the temples of the rows of the spirited elephants presented by the hundreds of kings defeated by the power of (the kings ) arms entangled with the series of rays issuing from the sharp swards"

It is found that the exhaustive list of donee's name in the DCPI and NPCPI of Bhaskarvarman and also found father's name of the done and their gotra in other inscriptions, yielding capacity of the donated land with issuing year also mentioned in some inscriptions.

The content of the last part of the inscriptions is the description of the donated land and the boundary of the land is demarcated by some trees, tanks, rivers, roads, etc. As for example we can cited-

" On the east, the Koppa and the land for transshipment of cows; on the east, the jam and the wood-apple tree, on the south, the trunk road and sovarna- daru tree; on the south east, the mango tree, on the west, the trunk road and the simalu tree; on the north west, the big banyan tree and the diddesa lake; on the north, half portion of seva pond; on the north-east, the tank and the fig tree" (NCPI of Bhaskarvarman)

Inscriptions of early Assam do not have any closing formula. Traditionally the future kings take care and show due honour to the past donees which we found in the inscription of NPCPI, was originally issued by Bhutivarman but later when it was lost King Bhaskarvarman himself reissued the character to the same or descendant of the donees, granting them the same privileges.

\section{Conclusion}

From the above discussion we come into conclusion that various factors of historical geography of early Assam, mainly inscriptions played an important role to depict an accurate history of early Assam. Application of new methods and techniques may endow the subject with a new orientation and a methodological and systematic way to examine the geographical changes that took place in the early days. Another important aspect of the study of historical geography is onomastics, a full blown brand of socio-linguistics study, which covers the domain of linguistics, geography, history, ecology, anthropology, sociology, etc. may appear as a good companion to historical geography.

In regard to the historiography of historical geography of early Assam has not scored much progressive in this field as some unresolved geographical issues are still impairing some crucial points of the history of Assam. Therefore an attempt has been made to focus on the study of historical geography and its methods and techniques; especially attention was made to depict the history of inscriptions as a factor for the study of the history of early Assam.

\section{References}

[1]. Studies in early history of Assam, ed. M.Neog, Asam sahitya Sabha, Jorhat, Guwahati, 1972

[2]. P.C.Choudhury, 'Historical Materials in the Carabari Copper Plate Grant of Ratnapalavarmadeva,JIH,Vol. LV, April-August, 1977, part I, II

[3]. The history of civilization of the people of Assam to the $12^{\text {th }}$ century A.D.,P.C.Choudhury, $3^{\text {rd }}$ ed. Delhi, Guwahati, 1987

[4]. The Mother Godess Kamakhya, B.Kakati, Publication Board Assam, Guwahati-1

[5]. The Comprehensive history of Assam, Vol. 1, Publication Board Assam, Guwahati, 1990

[6]. A Cultural history of Assam, Lawyer's Book stall, Guwahati, 1969

[7]. Early Geography of Assam, K.K.Baruah, Nowgong, 1952

[8]. Early History of Kamrupa,Barua, K.L. $3^{\text {rd }}$ ed., Lawyer's Book stall, Guwahati, 1998

[9]. Archaeology of theBrahmaputra valley of Assam,R.D.Choudhury Agam Kala Prakashan, Delhi, 1987

[10]. A Cultural history of North-East India (Assam ) Vol.-1, B. Chakravarty, self Employment Bureau (publications), Calcutta, 2000

[11]. Early Assam, state formation, political centres, cultural zones, Nirode Boruah, Spectrum Publications, Guwahati, Delhi, 1978 